\title{
Classification of Wounds at Risk and Their Antimicrobial Treatment with Polihexanide: A Practice-Oriented Expert Recommendation
}

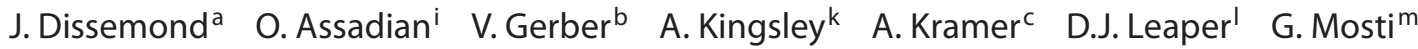 \\ A. Piatkowski de Grzymala ${ }^{d} \quad$ G. Riepe ${ }^{\text {eff }} \quad$ A. Risse ${ }^{g} \quad$ M. Romanellin ${ }^{n} \quad$ R. Strohal ${ }^{j} \quad$ J. Traber ${ }^{\circ}$ \\ A. Vasel-Biergans ${ }^{\text {h }} \quad$ T. Wild $^{p} \quad$ T. Eberlein $^{p}$
}

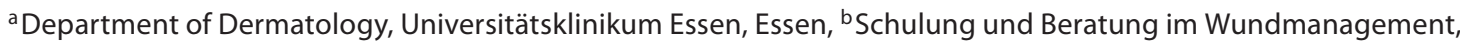
Spelle, 'Institut für Hygiene und Umweltmedizin, Ernst Moritz Arndt University, Greifswald, dKlinik für Plastische Chirurgie, Hand- und Verbrennungschirurgie, Universitätsklinikum der RWTH Aachen, Aachen, e'Stiftungsklinikum Mittelrhein, Akademisches Lehrkrankenhaus, Johannes Gutenberg University, Mainz, ${ }^{\mathrm{f}}$ Gesundheitszentrum Evangelisches Stift Sankt Martin Koblenz gGmbH, Koblenz, ${ }^{9}$ Diabeteszentrum, Medizinische Klinik Nord, Klinikum Dortmund gGmbH, Dortmund, and ${ }^{\mathrm{h}}$ Apotheke Klinikum Stuttgart, Stuttgart, Germany; ${ }^{\text {CClinical Institute for }}$ Hygiene and Medical Microbiology, Vienna General Hospital, Medical University of Vienna, Vienna, and ${ }^{\mathrm{j} A b t e i l u n g}$ Dermatologie, Landeskrankenhaus Feldkirch, Akademisches Lehrkrankenhaus, Feldkirch, Austria; ${ }^{\mathrm{k}}$ Infection Control and Tissue Viability, Northern Devon Healthcare Trust, North Devon District Hospital, Barnstable, and 'Department of Wound Healing, Cardiff University, Cardiff, UK; ${ }^{\mathrm{m} C l i n i c a}$ M.D. Barbantini, Lucca, and ${ }^{\mathrm{n}}$ Wound Healing Research Unit, Department of Dermatology, University of Pisa, Pisa, Italy; ${ }^{\circ}$ Venenklinik Kreuzlingen, Kreuzlingen, Switzerland; ${ }^{\mathrm{P}}$ Vascular and Endovascular Unit, Department of Surgery, Salmaniya Medical Center, College of Medicine and Medical Sciences, Arabian Gulf University, Manama, Kingdom of Bahrain

\section{Key Words}

Wound at risk score (W.A.R. score) $\cdot$ Wound at risk of infection - Polihexanide

\begin{abstract}
Currently, there are no generally accepted definitions for wounds at risk of infection. In clinical practice, too many chronic wounds are regarded as being at risk of infection, and therefore many topical antimicrobials - in terms of frequency and duration of use - are applied to wounds. Based on expert discussion and current knowledge, a clinical assessment score was developed. The objective of this wounds at risk (W.A.R.) score is to allow decision-making on the indication for the use of antiseptics on the basis of polihexanide. The proposed clinical classification of W.A.R. shall facilitate the decision for wound antisepsis and allow an appropriate general treatment regimen with the focus on the prevention of wound infection. The W.A.R. score is based on a clinically
\end{abstract}

oriented risk assessment using concrete patient circumstances. The indication for the use of antiseptics results from the addition of differently weighted risk causes, for which points are assigned. Antimicrobial treatment is justified in the case of 3 or more points. $\quad$ Copyright $\odot 2011$ S. Karger AG, Basel

\section{Introduction and Problem}

To date, there is no generally accepted definition for risk wounds, synonymously referred to as wounds at risk (W.A.R.) or wounds at risk of infection.

Because of the lack of a clear definition, many wounds are classified as being 'potentially at risk of infection'. Therefore, the excessive use - in terms of frequency and duration - of topical, antiseptically efficacious products is often the expression of a non-evidence-based empirical safety consciousness. On the other hand, it is important

\section{KARGER}

Fax +41613061234 E-Mail karger@karger.ch www.karger.com
() 2011 S. Karger AG, Basel

$1660-5527 / 11 / 0245-0245 \$ 38.00 / 0$

Accessible online at:

www.karger.com/spp
Thomas Eberlein, MD

C. de Cender 3

ES-07141 Sa Cabaneta (Spain)

Tel. +49 173201 2299, E-Mail thomaseberlein@ @otmail.com 
to identify at-risk patient groups or critical wound conditions in order to prevent serious infections, by consistency in wound management practices.

\section{Objective}

The expert recommendation presented here aims at contributing to the clarification of the term 'risk wound' and to provide an aid in the decision process as to which situations justify the use of antiseptics as a therapeutic measure for preventing wound infections. Since evidence-based guidelines regarding this topic are mostly missing, this recommendation reflects the consensus of an interdisciplinary and interprofessional expert group in the assessment of the current medical state of knowledge and their own clinical experience [1].

Polihexanide was selected as an antiseptic reference substance because of its favourable benefits and risks in wound care, which is supported by considerable evidence [2-4].

\section{Factors Relating to Risk Assessment}

Not only the existing pathogen burden and the type(s) of pathogens are of importance, but also their virulence and the interactions with the patient's resistance. These all play an important role in assessing the question of the probability of development of a wound infection.

The following general infectiological equation clarifies the correlation:

infection risk $=\frac{\text { number of pathogens } \times \text { pathogenicity of the pathogens }}{\text { patient's immune system }}$

(adapted from Archibald and Hierholzer [1]).

This means for example: the greater the denominator, i.e. the better the patient's state of immune competence, the lower the probability of infection. On the other hand, by reduction of the numerator, particularly by reduction of the number of pathogens, the risk of infection can also be reduced.

\section{Pathogen Burden}

The microbiological evidence of the presence of micro-organisms on a wound, healing by secondary intention, is not automatically equivalent to an infection. De- pending on the pathogen count, the proliferation behaviour, and the immunological response of the host, the following microbial wound situations are differentiated:

- contamination, i.e. micro-organisms are present and have attached to the tissue (microbial attachment), without (initial) proliferation;

- colonization, i.e. micro-organisms are present and are proliferating; a clinically significant immunological host reaction is (initially) absent;

- critical colonization, i.e. significant microbial proliferation without the formation of classical signs of infection but delayed wound healing due to toxin production, for example;

- local infection, i.e. clinically observable, immunological host reaction with the typical signs of infection including redness (erythema $>2 \mathrm{~cm}$ measured from the wound margin with tendencies of increase could be equivalent to spreading infection with the risk of generalization) [5], swelling, increased local skin/tissue temperature, pain, functional impairment, and increase in exudate quantity and viscosity, for example, perceptible odour and stagnation in wound healing $[5,6]$;

- generalized infection, i.e. in addition to the local inflammatory reactions, signs of a systemic host reaction such as leucocytosis, increase in C-reactive protein and fever may be observed [7].

The purely quantitative consideration of the microbial load of a wound (e.g. a guide value of $>10^{5}$ pathogens per gram of tissue) cannot be implemented as standard in clinical routine and is not sufficient to be able to assess the degree of the infection risk in wounds in general. Accompanied by a poor immune response of the patient and/or a special pathogenicity of the pathogen, wound contamination with virulent pathogens can already represent a risk for the patient despite a low pathogen load. A typical example is colonization with methicillin-resistant Staphylococcus aureus (MRSA).

The concept of 'critical colonization' continues to be controversially discussed, because it cannot be accurately defined from a microbiological or from a clinical point of view but is widely used in practice [6]. Here, too, the two factors of pathogen virulence and immune competence of the patient are coresponsible for whether or not a colonized wound develops into a critically colonized or an infected wound. Accordingly, in the course of wound healing the occurrence of the aforementioned clinical signs and symptoms of wound infection must be carefully heeded. Local and/or systemic antimicrobial measures must be taken, if necessary. 


\section{Microbiological Evidence and Pathogenicity of the Pathogen}

Regardless of the pathogen-harvesting technique (qualitatively using surface swabs, semiquantitatively using an expanded surface swab examination or quantitatively using a rinsing technique or tissue biopsy), current microbiological standard diagnostics for wound investigation are characterized by a number of drawbacks. Essentially, the following factors limit the value of microbiological standard diagnostics in the context of wound treatment [8]:

- the recovery rate of pathogens from the wound;

- the effectiveness of sampling types, e.g. swab versus biopsy;

- the only limited predictive value on relevance of the potentially demonstrated pathogens;

- the time required for the preparation of the microbiological findings;

- the chronicity of the wound;

- the localization (e.g. depth) of bacteria.

Reproduction of the results with respect to the reproducibility rate of the micro-organisms is frequently unsatisfactory. It is generally a local material removal that insufficiently includes the deeper parts of the floor of the wound. Moreover, the pathogens responsible for maintaining impaired wound healing or wound infection may be protected under a biofilm which can elude identification [8].

Even in the event of one or several species of microorganisms being present, the predictive value of standard microbiological sampling is limited with respect to clinical relevance. As a rule, the standard findings provide only information on genus (class) and species (type) of the micro-organisms, if necessary, as well as their sensitivity to selected antibiotics. Information on the presence or absence of specific pathogenicity factors is not provided. The pathogenicity of a microbial strain depends on the virulence factors that a particular microbial strain produces. Accordingly, relevant virulence factors such as the production of the enzymes coagulase, metalloproteinases or staphyloxanthin, a carotenoid pigment that has both cytotoxic and anti-oxidative effects, are - in terms of maintaining a wound infection - more probable in $S$. aureus isolates than for example in Staphylococcus epidermidis isolates, but they are also strain dependent within a species. The 'classical' microbiological finding does not distinguish between pathogens and less pathogenic strains of a species. The only statement on virulence can be taken from the anal- ysis of sensitivity to antibiotics. However, this analysis is only of indirect relevance, because the possible antibiotic resistance is relevant only when systemic antibiotic treatment is necessary. However, in the event of secondary sepsis resulting from a wound infection, knowledge of antibiotic sensitivity is often crucial for the patient's prognosis $[9,10]$.

Another limitation results from the required time of 2-5 days for growth of bacterial cultures following sampling (point of clinically identified risk) and availability of a microbiological result. A deterioration of the patient's condition up to the manifestation of infection can already have occurred in this interval $[7,9,10]$.

In principle, easy-to-use 'rapid tests' are available, but these tests are highly specific for selected pathogens and have been insufficiently studied in practical application. Currently, there is a need for action as early as the time of identification of the clinical problem. The results of the microbiological diagnostics can then later either confirm or reject this decision. In the event of a transition to a systemic infection, the microbiological findings admittedly facilitate the selection of necessary options for systemic therapy (e.g. the selection of the appropriate antibiotic) and provide, with respect to epidemiological considerations, information on the locally expected spectrum of pathogens $[7,9,11,12]$.

One aspect of the microbiological findings focusing on the pathogen, including its antibiotic resistance profile which should be considered separately, relates to the detection of multiresistant bacteria. Herein included are the MRSA strains, including community-acquired MRSA strains with a high risk of necrotizing infection, extended-spectrum $\beta$-lactamase-producing Gram-negative bacteria or glycopeptide-/vancomycin-resistant enterococci. When these pathogens are present, an antiseptic measure is always justified, because antibiotic-resistant bacteria even if they lack strain-dependent specific virulence factors for causing a local wound infection - have prognostically less favourable effects on the affected patient in the event of a systemic infection, but also on neighbouring patients in the event of accidental transmission (crosscontamination) $[5,9,10,12-15]$.

\section{Immunological Status of the Patient}

Clinical experience has shown that in an otherwise generally healthy person, who has an isolated chronic venous leg ulcer, the ulcer can persist for years without infection [16]. A chronic wound is not necessarily to be con- 


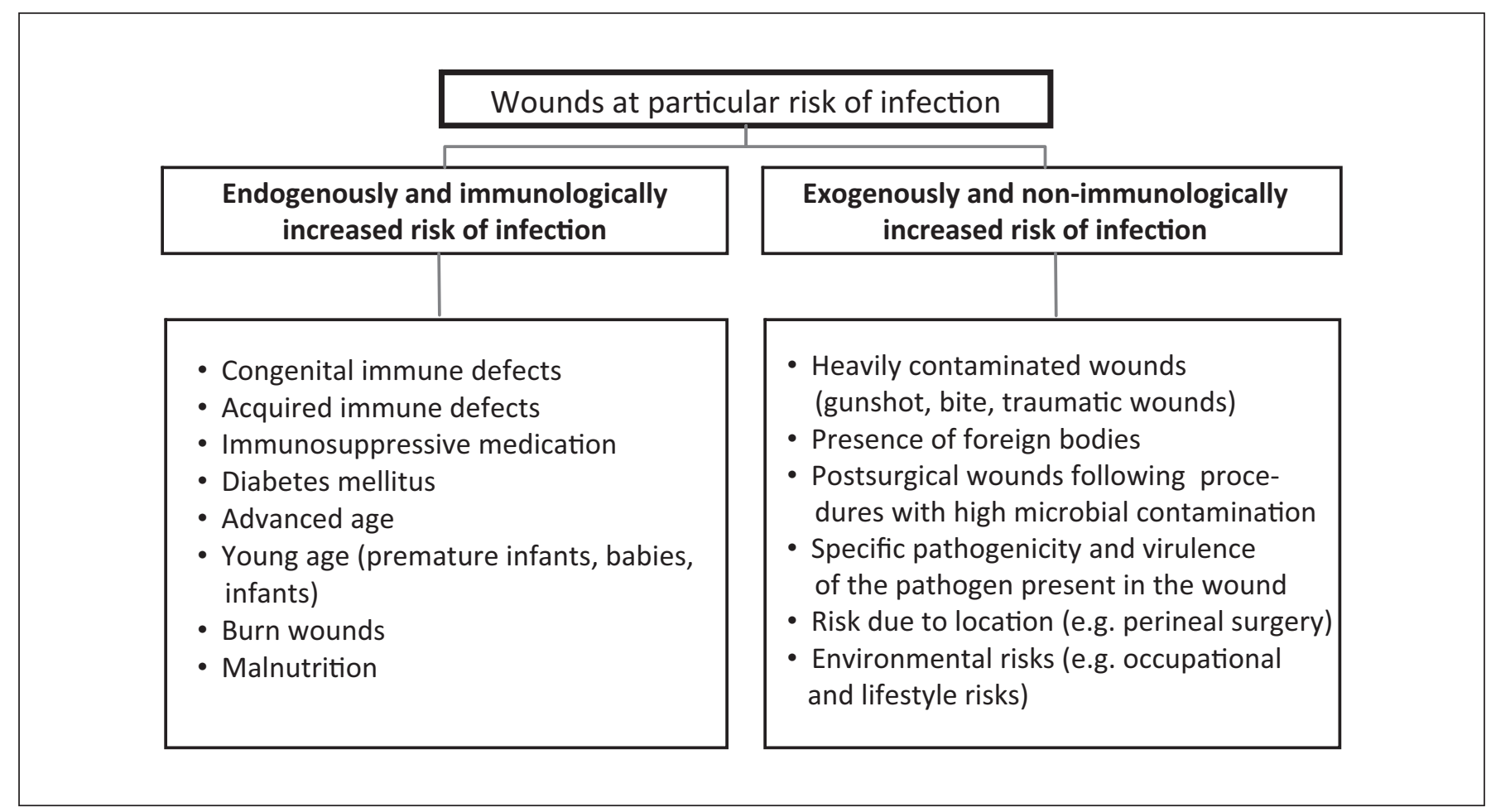

Fig. 1. Risk factors for wound infection.

sidered as a risk wound. On the other hand, the factors that impair a patient's immune competence are frequently the same - such as poorly controlled diabetes mellitus, immunosuppressives, malnutrition or arterial circulatory disorders - that are also responsible for delayed wound healing. These factors may of course contribute to chronicity. The actual infection risk of patients both with chronic and acute wounds depends critically on their basic immunological situation.

\section{Risk Wounds (W.A.R., Wounds at Risk of Infection)}

From the clinical point of view, the causes of a particular infection risk can be divided into two groups (fig. 1):

- the endogenous factors have an effect on the development of a wound infection and can essentially be traced back to a weakening of the patient's immune system;

- the external (exogenous) factors weighing upon the wound situation are related to the quantity and pathogenicity of the pathogen and its susceptibility to the antiseptic agent.

\section{Wounds with Endogenous Infection Risk}

The term 'immunosuppression' generally describes the activities in which immunological processes are suppressed. In the immunosuppressed patient, complicated and frequently also chronic wounds occur increasingly. These can be subdivided into neoplasms (e.g. squamous cell carcinoma), infections (e.g. lues maligna), vasculitides (e.g. secondary vasculitis in systemic lupus erythematosus) and specific wounds (e.g. ulcerating graft-versushost disease). In particular, the bacterial superinfections in the course of erysipelas, a phlegmon up to the development of sepsis, are dreaded complications and occur more frequently in mmunosuppressed patients compared with those who are immunocompetent.

Fundamentally, the distinction must be made between congenital and acquired immune defects in patients with an immunological disorder.

\section{Congenital Immune Defects}

Defects in antibody production constitute the majority (about 50\%) of all congenital immune defects. Examples of these diseases include agammaglobulinaemia, 
common variable immunodeficiency and hyper-IgM syndrome. Other congenital immune defects are based on B-cell defects such as the Bruton-Gitlin syndrome, on T-cell defects such as Nezelof syndrome or on combined B-cell and T-cell defects such as severe combined immunodeficiency, Wiskott-Aldrich syndrome, Di George syndrome or Louis-Bar syndrome.

\section{Acquired Immune Defects}

The substantially more commonly occurring acquired immune defects can be caused, for example, by the following factors [17-20]:

- infectious diseases such as AIDS, cytomegaly or measles;

- neoplasms, e.g. leukaemia, lymphoma;

- medicines, e.g. glucocorticoids;

- auto-immune diseases, e.g. systemic lupus erythematosus or rheumatoid arthritis;

- decreased cellular immune response and cellular senescence;

- age;

- malnutrition;

- splenectomy;

- burns;

- diabetes mellitus.

\section{Immunologically Relevant Medicines}

In the case of medicines, the relevant active substance groups can be divided into:

- glucocorticoids, e.g. prednisone, prednisolone or dexamethasone, which have a direct inhibitory effect on T cells and an indirect effect also on B cells;

- cytostatic agents, e.g. alkylating agents such as cyclophosphamide or melphalan, which block cell division by insertion of alkyl groups into the DNA, antimetabolites such as methotrexate or azathioprin, which as purine, pyrimidine or folic acid analogues block both DNA and RNA synthesis, and intercalators such as doxorubicin or mitoxanthrone, which bind non-covalently to the DNA and thus block its replication;

- antibodies, e.g. anti-CD3 (catumaxomab), anti-CD20 (rituximab) or anti-CD25 (basiliximab);

- immunosuppressive agents, by which alteration of immunophilins, e.g. with cyclosporine, tacrolimus or sirolimus, results, for example, in T-cell inhibition via inhibition of calcineurin.

Finally, there are also other immunosuppressive medicines of which mycophenolate mofetil, which inhibits B cells and T cells through the inhibition of the synthesis of guanosine nucleotides, is an example [19].

Classification of Wounds at Risk and Treatment with Polihexanide
Infection Risk in the Context of Diabetic Foot

Syndrome, Diabetic Podopathy

Peripheral neuropathy with loss of important sensory, motor and autonomic functions is the most important cause of ulceration, which occurs after trauma or by pressure causing deformations of the feet in diabetic patients.

Among the factors that can favour wound infection in patients who have diabetes is the deficient acid-protective coat of the skin caused by sebostasis and sudomotor impairment, associated with cracks, fissures and skin defects triggered by mycoses, which facilitate invasion by pathogens and a high pathogen diffusion due to absent sensory warning signals. Likewise, reduced arterial circulation to the lower extremity can also be a significant factor. According to current knowledge, it is certain that micro-angiopathy does not result in occlusion of the arterioles and capillaries. However, thickened basal membranes, which cause poorer oxygen permeation into the tissue, is observed in the small arterioles. However, due to the loss of autonomic control of the arteriovenous shunts and loss of postural constriction, there is permanent hyperperfusion. Glycated haemoglobin transports less oxygen in diabetic patients, and in addition, the reduced deformability of the erythrocytes causes poorer oxygen supply to the tissues. The resulting perturbed protein synthesis following hypoxia also results in a reduced local resistance to infection [21-23].

The generalized reduced immune response in patients who have diabetes is attributed to a limited leucocyte and monocyte activity, with a reduction of chemotaxis and phagocytosis. Systemic and local immune deficits also account for the fact that the classical inflammatory reactions like fever or leucocytosis seen in wound infections are absent in a large proportion of patients with diabetes [22-26].

\section{Infection Risk in the Context of Burns and Scalds}

Burns and scalds are thermal damage to the skin and connective tissues; a burn is damage by fire or contact with hot objects, a scald is caused by hot liquids or steam.

Infections are among the feared complications whereby, in extensive burns, sepsis is the cause of a fatal outcome in more than 50\%. Approximately 1 week after a burn, it can be assumed that every burn wound is microbially colonized or already infected. Ideal conditions for micro-organisms are found on burn and scald wounds. Due to the sustained destruction of the skin barrier, the reduced general immune defence and the deteriorated microcirculation, this risk is explainable [17, 20, 27-29].

Skin Pharmacol Physiol 2011;24:245-255 


\section{Wounds with Exogenous Infection Risk}

Infection Risk in Postoperative or Iatrogenic Wounds Unplanned secondary wound healing, following skin dehiscence, in a postsurgical wound intended for primary closure, frequently results in a particular risk of microbial wound healing disorders $[12,30,31]$.

\section{Gunshot, Bite and Contaminated Wounds}

Heavily Contaminated Wounds

Abrasions, lacerations, crush and impalement wounds inflicted outdoors can be heavily exogenously contaminated. In addition to the dermal flora, including MRSA, for example, primarily Clostridium and Bacillus spp., even Rabies Virus, can be introduced into the wound.

\section{Bite Wounds}

A bite wound is a tissue injury that is inflicted by a person or by an animal. About $60-80 \%$ of bite injuries are caused by dogs, $20-30 \%$ by cats. In rural areas, human bites are rare; in cities, they can reach up to $20 \%$ of bite injuries. The greatest concern in a bite wound is the transmission of infectious diseases such as tetanus, hepatitis or rabies. Damage to tendons, muscles or nerves can also occur. While the transmission of zoonoses such as rabies, cat scratch disease, cat pox, rat bite fever, tularaemia, brucellosis or leptospirosis is rare following an animal bite, and tetanus has become rare following an animal bite or accidental trauma, wound infections can run a serious course, including disseminated infection and sepsis, particularly when caused by oral flora. In the case of bite injuries - in part due to the selective diagnostic methods used - only few bacterial strains are isolated from the wound. Thus, in cat and dog bites, Pasteurella canis, Pasteurella multocida or Mannheimia haemolytica are most commonly isolated, whereas S. aureus, Streptococcus pyogenes, Canocytophaga canimorsus, Neisseria and Moraxella spp. are rarer causes of wound infection. Anaerobic organisms can be found in $39 \%$ of animal and in $50 \%$ of human bite wounds. Frequent anaerobic organisms are Bacteroides, Fusobacterium, Peptococcus, Veillonella, Porphyromonas and Prevotella spp. In bite wounds inflicted by humans, wound infections, also including systemic infections, can be caused by Eikenella corrodens, $\beta$-lactamase-resistant anaerobes, extended-spectrum $\beta$-lactamase-producing forms and MRSA. Finally, the possibility of transmission of hepatitis $\mathrm{B}$ and syphilis must be considered; it must be kept in mind that cat bites are associated with a higher infection rate than dog bites, because of the puncture-like bite wound and the deeper inoculation of the pathogens. Depending on location, the infection risk averaged $\geq 20 \%$ in bite injuries caused by human beings, and after dog bites it was between 3 an 17\%, respectively [32].

As no demonstration of a pathogen can initially be made, the risk of a wound infection must be minimized to the greatest possible extent in conjunction with the use of antiseptics and antibiotics.

While primary closure of bite wounds to the face and head is unquestionably the method of choice, the notion is increasingly taking hold that also in other regions delayed closure should be considered only for wounds already infected and for wounds at particular risk of infection, because surgical care in conjunction with antisepsis determines the success of treatment to a considerable degree. Better cosmetic outcomes together with quicker wound healing can be achieved after primary closure. Primary suture can be undertaken within a period of up to $12 \mathrm{~h}$ after surgical treatment, antisepsis and, if required, single-shot antibiotic prophylaxis. Even infected wounds can be primarily closed after installation of a drain [32].

\section{Gunshot Wounds}

Gunshot wounds are a special type of acute, traumatic wound. They are caused by the blunt force of projectiles or projectile particles and are a combination of laceration and crush wounds. The projectile causes a direct tissue laceration upon entry, exit and traversing of the body related to the kinetic energy of the projectile $\left(1 / 2 \mathrm{mv}^{2}\right)$. Depending on the shape of the projectile, the tissue yielding to the sides of the projectile experiences a high radial acceleration with significant heat development and tissue destruction (cavitation effect). Injuries with mole guns are particularly dangerous because contaminated soil is carried into the depths of the wound.

In the case of gunshot wounds, exploration and debridement of the projectile channel and the exit wound, and - if applicable - vessel reconstruction, bone stabilization using an external fixator, and exploration of the abdominal and thoracic cavity must be considered $[12,14$, 33].

\section{Environmental Risks}

Because the skin plays an essential role in infection defence, the wound represents a potential risk, which may present differently depending on external conditions such as occupation, personal hygiene and the location of the wound. 
Occupational Risk

Many patients with chronic wounds are still able to work. In a study for the 2007 Disease Management Program, the average age of patients with chronic wounds was $68( \pm 12)$ years. Particularly in rurally structured living environments, many persons work in agriculture beyond the retirement age. This results in hygienically difficult conditions due to the pathogen burden in the environment, footwear and clothing. Similarly problematic are, for example, occupations on building sites, in automotive workshops, in ports, in recycling sites and waste depots, or in woodworking operations. Therefore, when taking a history from a patient, the recording of social data and evaluation of the occupational environment are important. For example, the provision of footwear with safety steel toes required by the employer impairs pressure relief, and pathogen proliferation in the shoes is favoured by the moist and warm environment. The same applies to rubber boots when working in a barn [16]

Lorry drivers are an occupational group that is at particular pressure risk. Due to the long periods of sitting on plastic seats without the opportunity to shift their weight, pressure points may occur in the sacral region. Many seek medical treatment late because they underestimate the problem, they are embarrassed or are afraid of losing their job. These skin lesions are at risk of infection due to the location of the wound and the unfavourable ventilation situation. Pilonidal sinus is also a typical problem in this occupational group.

Occupational risks must not be underestimated in healthcare workers either. Different facultative pathogens or pathogenic disease organisms are found in hospitals, medical practices and nursing homes. In the case of injuries, this may present a particular risk (e.g. infection with MRSA) [34].

\section{Influence of Personal Hygiene}

Handling dressings with inadequate hand hygiene increases the risk of wound infection. Gardening, as well as do-it-yourself activities or cleaning, also contains a potential risk. Pseudomonads and other aqueous pathogens can colonize water lines, showerheads and faucet aerators and can be transmitted when flushing wounds. Hygiene deficiencies can also result in cross-contamination with respect to foot baths [35].

Risk due to Wound Location

Particular body regions have a higher microbial burden than others $[27,35]$. This applies to the perineal region, the feet, facial wounds or abdominal wounds with existing anus praeter. Due to the more difficult fixation of dressings, hair-covered skin represents, primarily from the hair follicles, a risk of infiltration or migration by wound pathogens [36]. This problem is also present in the case of wounds in the area of external fixators, probes, tracheal cannulas and catheters [37].

Furthermore, the patient's individual medical situation needs to be considered. Systemic antibiotic prophylaxis is recommended in patients with risk for endocarditis, e.g. patients with known vulnerable cardiac valves, mechanical cardiac valves or presence of permanently implanted prosthetic medical devices.

Wounds are at potential risk of infection by virtue of unfavourable external circumstances. Careful analysis of living conditions related to hygienic conditions and the patient's activities is necessary, in order to determine the individual risk $[16,38]$.

\section{Risk Score: The W.A.R. Score}

The creation of a checklist in the form of a score for risk wounds (table 1) serves the objective of enabling a clinically oriented elaborate risk assessment using specific patient circumstances. The indication for use of antiseptics results from the addition of differently weighted risk causes, for which points are assigned. Antimicrobial treatment is justified in the case of 3 or more points.

This score represents a recommendation which is open for discussion and which was formulated due to the absence of evident data based on comprehensive clinical experience. It needs to be verified in practice and continuously adapted.

\section{The Role of Polihexanide in Risk Wounds}

In view of the known actions of polihexanide and its positive risk-benefit evaluation, it appears to be advantageous to use preparations containing polihexanide in the risk situations described above with the clear indications of the risk wound $[3,7,39,40]$.

Bite injuries are an exception. In these cases, surfaceactive antiseptics like octenidine, polihexanide or chlorhexidine could theoretically support eradication by virtue of their surface tension but may not be active in the depth of wounds in contrast to alcohols and povidoneiodine, which can even be systemically absorbed. The absence of absorption of these active substances when used on wounds may favour this hypothesis in contrast 
Table 1. Classification for wounds at risk: the W.A.R. score

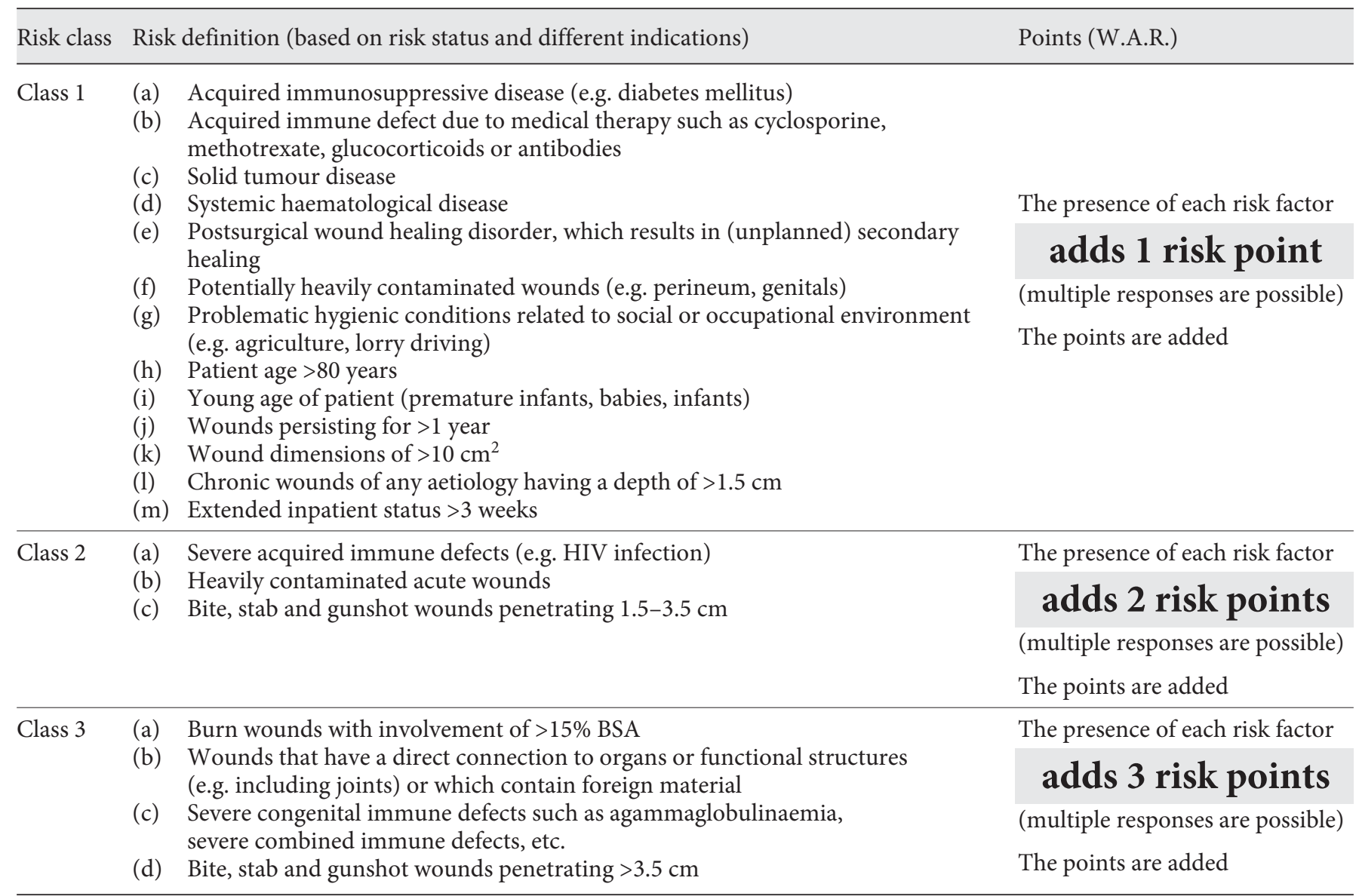

Finally, the risk factor points are added to obtain a total score. A score $\geq \mathbf{3}$ points indicates the presence of a wound clinically at risk of infection and consequently represents a clinical indication for the administration of local antiseptics.

BSA = Body surface area.

Regardless of this recommendation, other treatment indications may be present, which themselves require local antimicrobial treatment such as: elimination of pathogens when multiply resistant pathogens are present specified by the Robert Koch Institute; critically colonized wounds.

to povidone-iodine and alcohols in this situation. Since the application of octenidine under pressure in stab injuries in the paediatric hand resulted in protracted oedematous adverse effects with tissue damage, pressurized administration into tissues is contraindicated. This would apply analogously to polihexanide and chlorhexidine. Flushing of deep wounds (e.g. bite injuries) with topically active strong protein-binding antiseptics is permissible only if drainage of the rinsing fluid is provided $[11,33,41-45]$.

The basics of the therapeutic use of polihexanide in infected wounds have been defined in another expert recommendation [7].
Table 2 provides an overview of the efficacy and tolerability of the substance.

Justified, longer-term, even repeated, application to risk wounds must be clearly delimited from this. The relevant risk factors are shown in table 1.

Overall, therapy with antiseptic solutions or supportive use of antimicrobial wound dressings is reasonable if it is integrated in a supervised clinical course of treatment. Here, the frequency of a change of dressing is dependent on the overall wound status. Daily change of dressings is often required for infected wounds. For wounds at risk of infection (W.A.R.) this is dependent on wound status and can be in a range of 2-7 days. Application must generally 
Table 2. Efficacy and tolerability of polihexanide

\begin{tabular}{ll}
\hline Efficacy & Tolerability \\
\hline $\begin{array}{l}\text { Broad antimicrobial effect } \\
\begin{array}{l}\text { Very low minimum blood/protein error (limitation of } \\
\text { effect on mucous membranes due to presence of mucin) }\end{array}\end{array}$ & Geod clinical tolerability \\
\hline After-effect, postantiseptic effect & $\begin{array}{l}\text { Biocompatibility index }>1 \text { [quotient from cell toxicity (IC }{ }_{50} \text { ) } \\
\text { and microbicidal efficacy }(\mathrm{RF}>\lg 3=\text { microbial count reduction by } \\
\text { more than } 3 \text { log units), tested in fetal bovine serum] }\end{array}$ \\
\hline Concentration-dependent promotion of wound healing [46] & No known toxic risks \\
\hline Anti-inflammatory properties & No known resorption risks \\
\hline No known development of resistance & Sustainability of the active ingredient \\
\hline Reduction of biofilm and fibrin formation [47] & Low risk of contact sensitization \\
\hline
\end{tabular}

be reviewed no later than 21 days. With a continuation of the risk (W.A.R.), the continuing therapeutic procedure must be decided on an individual basis [7].

When there is suspicion of deep transmitted infection, systemic antimicrobial therapy must be inaugurated $[5$, $7,12]$.

\section{Use, Available Preparations and Route of Administration}

In wound antisepsis, polihexanide solutions are commonly used at concentrations of $0.01,0.02$ and $0.04 \%$. The solution should be used only for local applications, e.g. for rinsing (lavage), rinse/suction drainage or moist wound dressings. Since polihexanide has a delayed action, and the individual pathogens respond to the agent with different levels of sensitivity over time, it is important to allow a minimum exposure time of $10-15$ min after the wound base has been thoroughly wetted. This is an intermittent, repeated use.

Polihexanide as an antimicrobial component in wound dressings or gels supplements the benefits of moist wound care with the increased security of a continuous eradication of wound pathogens.

The polihexanide-containing products used in the context of wound care differ in their forms of administration (antiseptics, wound flushing solutions, gels, wound dressings) and have different properties by virtue of their different vehicles. They have specific indications (antiseptic $=$ drug) or intended uses (medical device) and must be evaluated differently for their clinical efficacy.

Classification of Wounds at Risk and

Treatment with Polihexanide
For this, it must be ensured that the products are used exclusively in accordance with their stated indications or intended uses [7].

\section{Contraindications}

According to the current state of knowledge, there are relative contraindications to the use of polihexanide: [2, $3,7,11,48-50]$ :

- for antiseptic joint lavage (cartilage toxicity);

- in applications involving any part of the central nervous system, including the meninges, and intralumbal/intrathecal applications;

- for applications involving the middle or inner ear, or for intra-ocular applications;

- during the first 4 months of pregnancy (at any time thereafter, a strict benefit/risk assessment has to be performed);

- in patients allergic to polihexanide.

\section{Conclusion and Summary}

The W.A.R. score described in table 1 is helpful for optimizing the risk evaluation of the wound at risk of infection. Classification of these risk wounds into a general therapy scheme is thereby simplified.

Because of the assignment of the different microbiological statuses and the clinical situation, a simple and practical grading scheme is described for the therapy of these wounds (fig. 2).

Skin Pharmacol Physiol 2011;24:245-255 


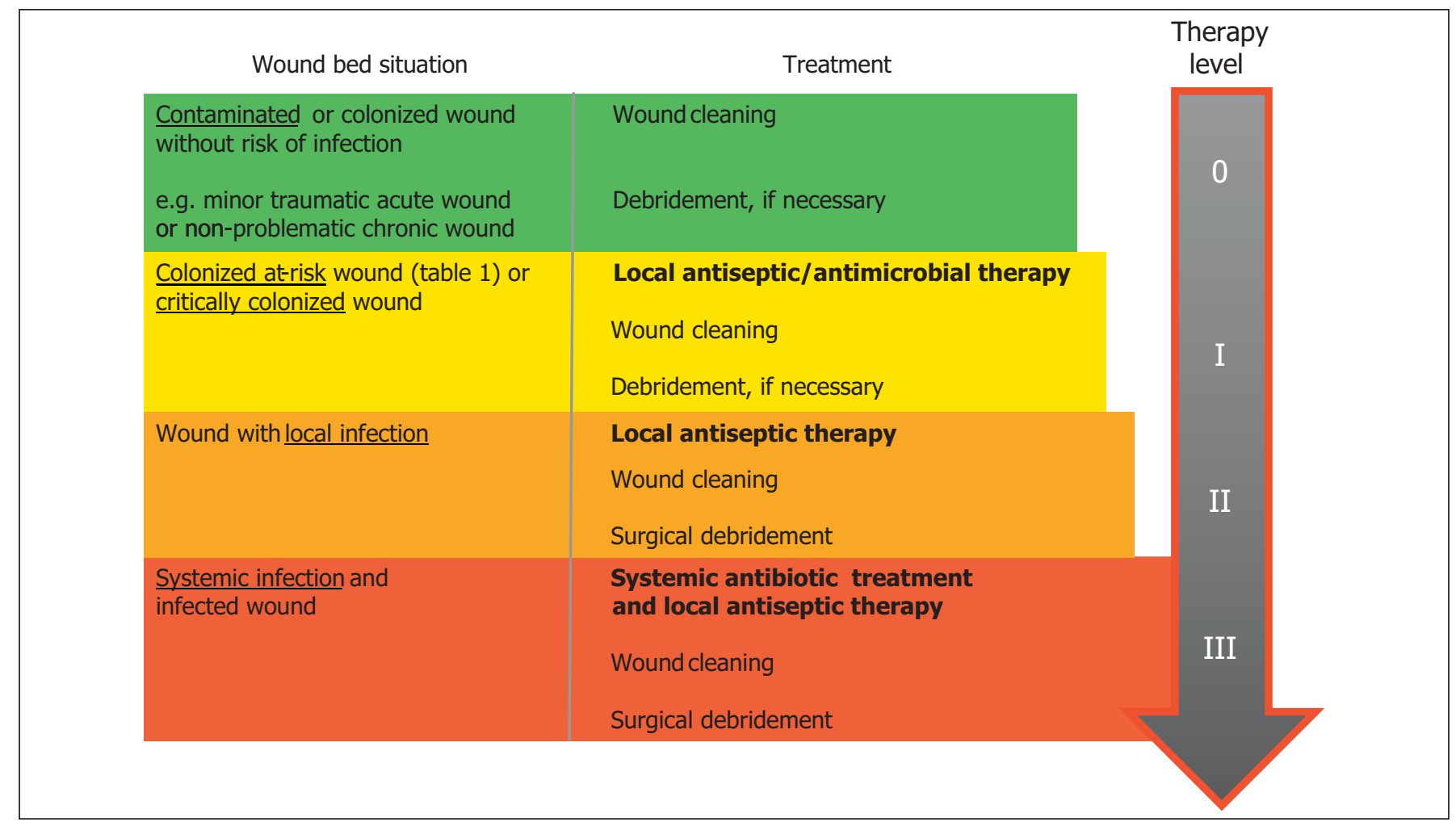

Fig. 2. Therapeutic steps for antimicrobial wound treatment.

This makes it possible to maintain a summarizable requirement-oriented selection of methods available in the clinical routine, and to adequately care for every wound after assessment of the concrete risk situation.

\section{Acknowledgements}

This work was supported by Lohmann \& Rauscher GmbH \& Co. KG, Rengsdorf, Germany, and by a Scientific Grant of Lohmann \& Rauscher GmbH \& Co. KG, Rengsdorf, Germany.

\section{References}

1 Archibald LK, Hierholzer WJ: Principles of infectious disease epidemiology; in Mayhall CG (ed): Hospital Epidemiology and Infection Control, ed 3. Philadelphia, Lippincott, Williams \& Wilkins, 2004, pp 7-8.

2 Eberlein T, Assadian O: Clinical use of polihexanide on acute and chronic wounds for anti-sepsis and decontamination. Skin Pharmacol Physiol 2010;23(suppl 1):45-51.

-3 Hübner NO, Kramer A: Review on the efficacy, safety and clinical applications of polihexanide, a modern wound antiseptic. Skin Pharmacol Physiol 2010;23(suppl 1):17-27.

4 Kaehn K: Polihexanide: a safe and highly effective biocide. Skin Pharmacol Physiol 2010;23(suppl 1):7-16.
5 Kingsley A, White R, Gray D, Cooper P: Using the wound infection continuum to assess wound bioburden (poster). Applied Wound Management Supplement. 2: Implementation. Wounds UK, Harrogate, 2006.

6 Dow G, Browne A, Sibbald RG: Infection in chronic wounds: controversies in diagnosis and treatment. Ostomy Wound Manage 1999;45:23-40.

7 Dissemond J, Gerber V, Kramer A, Riepe G, Strohal R, Vasel-Biergans A, Eberlein T: Praxisorientierte Expertenempfehlung zur Behandlung kritisch kolonisierter und lokal infizierter Wunden mit Polihexanid. Z Wundbehandlung 2009;14:20-26.
Kirketerp-Møller K, Jensen P, Fazli M, Madsen K, Pedersen J, Moser C, Tolker-Nielsen T, Høiby N, Givskov M, Bjarnsholt T: Distribution, organization, and ecology of bacteria in chronic wounds. J Clin Microbiol 2008;46: 2717-2722.

9 Al Ghazal P, Körber A, Dissemond J: Nachweis der bakteriologischen Kolonisation chronischer Wunden in Abhängigkeit von dem $\mathrm{pH}$-Wert und der Lokalisation der Abstrichentnahme. Med Rep 2008;32:11.

10 Bowler PG, Duerden BI, Armstrong DG: Wound microbiology and associated approaches to wound management. Clin Microbiol Rev 2001;14:244-269. 
11 Kramer A, Roth B: Polihexanid; in Kramer A, Assadian O (eds): Wallhäussers Praxis der Sterilisation, Desinfektion, Antiseptik und Konservierung. Stuttgart, Thieme, 2008.

12 Sibbald RG, Orsted HL, Schultz GS, et al: Preparing the wound bed 2003: focus on infection and inflammation. Ostomy Wound Manage 2003;46:24-51.

$\checkmark 13$ Bowler P: The $10^{5}$ bacterial growth guideline: reassessing its clinical relevance in wound healing. Ostomy Wound Manage 2003;49:44-53.

-14 Sibbald RG, Williamson D, Orsted HL, et al: Preparing the wound bed - debridement, bacterial balance and moisture balance. Ostomy Wound Manage 2000;46:14-35.

15 Sibbald RG, Meaume S, Kirsner RS, Munter KC: Review of the clinical RCT evidence and cost-effectiveness data of a sustained-release silver foam dressing in the healing of critically colonised wounds. WUWHS Symposium, Paris, 2004.

-16 Rabe E, et al : Bonner Venenstudie der Deutschen Gesellschaft für Phlebologie. Phlebologie 2003;32:1-14.

17 Baindurashvili AG, Brazol MA, Mitrofanova, EV, Tsvetaeva, EV, Melnikov MR: Successful treatment of a patient with major third-degree burns with a hydrobalanced biocellulose dressing (poster). European Wound Management Association, Helsinki, May 20-22, 2009. EWMA J Suppl 2009;9: 211.

18 Denyer J: The use of Hydrobalance cellulose based dressings in the management of children with epidermolysis bullosa (poster). Wounds UK, Harrogate, 2009.

19 Pangos M, Spazzapan L, Papa G, Arnez ZM: Successful treatment of systemic scleroderma ulcers by means of an antimicrobial Hydrobalance wound dressing (poster). European Wound Management Association, Helsinki, May 20-22, 2009. EWMA J Suppl 2009;9:231.

20 Piatkowski A, Ulrich D, Abel M, Pallua N: First experiences with a hydrobalancing wound matrix (Suprasorb X) in the treatment of minor burns (poster). European Wound Management Association, Lisbon, May 14-16, 2008. EWMA J Suppl 2008;8:191.

-21 Caputo GM, et al: Assessment and management of foot disease in patients with diabetes. N Engl J Med 1994;331:845-860.

22 Greitemann B: Das diabetische Fusssyndrom. Dtsch Med Wochenschr 1997;8:243244.

23 Risse A: Das diabetische Fuss-Syndrom klassische Behandlungsverfahren der infizierten Problemwunde. GMS Krankenhaushyg Interdiszip 2006;1:24
24 Brunner U, Zollinger H: Wieviel Fuss ist besser als keiner (Kongressbericht). Langenbecks Arch Chir 1989;2(suppl):621-622.

25 Lipsky AB, Berendt AR: Infection of the foot in persons with diabetes: epidemology, pathophysiology, microbiology, clinical presentation and approach to therapy; in Boulton AJM (ed): The Foot in Diabetes, ed 4. New York, Wiley \& Sons, 2006.

26 Nationale Versorgungsleitlinie Typ-II-Diabetes. http://www.versorgungsleitlinien.de/ methodik/nvl-archiv/vorversionen-dm2fuss/nvl-dm2-fuss-lang-2.7.pdf.

27 Daeschlein G, Assadian O, Bruck JC, Meinl C, Kramer A, Koch S: Feasibility and clinical applicability of polihexanide for treatment of second-degree burn wounds. Skin Pharmacol Physiol 2007;20:292-296.

28 Kamholz L: Verbrennungsbehandlung. Österr Ärzteztg 2007, No 13/14.

29 Kramer A, Bruck J, Eisenbeiss W, Meierhans $\mathrm{R}$, Rudolph P: Hygiene an einer Intensivstation für Brandverletzte; in Bruck JC, Müller FE, Stehen M (eds): Handbuch der Verbrennungstherapie. Landsberg, Ecomed, 2002.

30 Nielsen AM, Fremmelevholm A: Hydrobalanced cellulose based wound dressing with polihexanide used in surgical wounds (poster). European Wound Management Association, Helsinki, May 20-22, 2009. EWMA J Suppl 2009;9:105.

31 Webster J, Osborne S: Preoperative bathing or showering with skin antiseptics to prevent surgical site infection. Cochrane Database Syst Rev 2007;18:CD004985.

32 Kramer A, Assadian O, Frank M, et al: Prävention postoperativer Wundinfektionen im Rahmen der chirurgischen Versorgung von Bissverletzungen. GMS Krankenhaushyg Interdiszip 2010;5:12.

33 Frank M, Schmucker U, Zach A, et al: Harm set, harm get: hand injuries caused by vole captive bolt devices. Forensic Sci Int 2008; 176:258-262.

34 Leaper D, McBain AJ, Kramer A, et al: Healthcare associated infection: novel strategies and antimicrobial implants to prevent surgical site infection. Ann R Coll Surg Engl 2010;92:453-458

35 Andriessen AE, Eberlein T: Assessment of a wound cleansing solution in the treatment of problem wounds. Wounds 2008;20:171-175.

- 36 Lademann O, Kramer A, Richter H, Patzelt A, Meinke M, Roewert-Huber J, Czaika V, Weltmann KD, Hartmann B, Koch S: Antisepsis of the follicular reservoir by treatment with tissue-tolerable plasma (TTP). Laser Phys Lett 2011;8:313-317.

37 Körber A, Seipp HM, Hofmann S: Efficacy of different wound dressings on artificial plaques of fibrin. EWMA J 2008;8:261.

38 Seipp HM, Hofmann S, Hack A, Skowronsky A, Hauri A: Wirksamkeit verschiedener Wundspüllösungen gegenüber Biofilmen. Z Wundbehandlung 2005;10:160-164.
-39 Hammann A, Hübner NO, Bender C, et al: Antiseptic efficacy and tolerance of tissuetolerable plasma compared with two wound antiseptics on artificially bacterially contaminated eyes from commercially slaughtered pigs. Skin Pharmacol Physiol 2010;23: 328-332.

40 Hirsch T, Jacobsen F, Rittig A, et al: A comparative in vitro study of cell toxicity of clinically used antiseptics. Hautarzt 2009;60: 984-991.

41 Goertz O, Ring A, Knie U, et al: Evaluation of a novel polihexanide-preserved wound covering gel on dermal wound healing. Eur Surg Res 2010;44:23-29.

-42 Koburger T, Hübner NO, Braun M, et al: Standardized comparison of antiseptic efficacy of triclosan, PVP-iodine, octenidine dihydrochloride, polyhexanide and chlorhexidine digluconate. J Antimicrob Chemother 2010;65:1712-1719.

43 Lipp C, Kirker K, Agostinho A, et al: Testing wound dressings using an in vitro wound model. J Wound Care 2010;19:220-226.

44 Romanelli M, Dini V, Barbanera S, et al: Evaluation of the efficacy and tolerability of a solution containing propyl betaine and polihexanide for wound irrigation. Skin Pharmacol Physiol 2010;23(suppl 1):41-44.

45 Wiegand C, Abel M, Ruth P, et al: HaCaT keratinocytes in co-culture with Staphylococcus aureus can be protected from bacterial damage by polihexanide. Wound Repair Regen 2009;17:730-738.

-46 Roth C, Beule G, Kramer A, et al: Response analysis of stimulating efficacy of polihexanide in an in vitro wound model with respiratory ciliary epithelial cells. Skin Pharmacol Physiol 2010;23(suppl 1):35-40.

47 Hübner NO, Matthes R, Koban I, et al: Efficacy of chlorhexidine, polihexanide and tissue-tolerable plasma against Pseudomonas aeruginosa biofilms grown on polystyrene and silicone materials. Skin Pharmacol Physiol 2010;23(suppl 1):28-34.

48 Berg A, Assadian O, Rudolph P, et al: Unverträglichkeit von Lavasept bei der Peritoneallavage am Modell der experimentell induzierten Peritonitis beim Meerschweinchen. Hyg Med 2008;33:189-193.

49 Bundesvereinigung Deutscher Apothekerverbände: Deutscher Arzneimittel-Codex DAC/Neues Rezeptur-Formularium NRF. Eschborn, Govi, 2008

50 Lauenstein P: Untersuchung zur Peritonealverträglichkeit von Polihexanid im Meerschweinchenmodell; Dissertation Medizinische Fakultät Universität Greifswald, 2007. 